\author{
Erdi Okan Yilmaz \\ $\mathrm{PhD}$, Doctor, Lecturer \\ Uşak University, Distance Education App. and Research Centre, Uşak, Turkey \\ ORCID ID 0000-0002-7423-725X \\ erdi.yilmaz@usak.edu.tr \\ Nurettin Şimşek \\ PhD, Professor, Doctor \\ Ankara University, Computer Education Instructional Technology Department, Ankara, Turkey \\ ORCID ID 0000-0002-9319-1875 \\ nsimsek@ankara.edu.tr
}

\title{
DESIGN AND DEVELOPMENT OF DISCUSSION-ORIENTED FLIPPED LEARNING ENVIRONMENT
}

\begin{abstract}
This research discusses the process of designing and developing a flipped learning environment, which is one of the blended learning approaches, through integrating the discussion environment in order to eliminate some of its limitations. In this context, in order to improve the interaction of students in various dimensions, the discussion environment was integrated into the traditional flipped learning environment. The environment was designed to be discussion-oriented so that students can access the learning content and discussion media simultaneously on the same screen. The method of research was determined as developmental research. In this regard, environmental design and development steps were followed in accordance with the developmental research steps. PHP, JavaScript and Mysql databases were used in environment developing processes. The system was built on WordPress content management system, the course videos were recorded in a professional studio environment, and editing and production stages were carried out by the researcher. The newly-designed and developed prototype environment was tested by both nine field experts and 42 undergraduate students studying at Uşak University in Turkey. To evaluate the pilot environment developed, "Expert Environment Assessment Form" was used to get expert opinion and "Pilot Application Evaluation Form and Opinion Questionnaire" was used to get student opinion. The expert opinion and evaluation form was comprised of three parts. General features of the discussion-oriented flipped learning environment were discussed in the first part, and the features of flipped learning environment were discussed in the second part. The last part included the items related to the visual design features of the new environment. In line with the opinions received, final evaluations were made, and the environment was put into its final form. In line with feedback from students and experts, it can be stated that turning the flipped learning environment into a discussion-oriented structure positively affects the satisfaction levels of students about the environment.
\end{abstract}

Keywords: discussion-oriented flipped learning; developmental research; flipped learning.

\section{INTRODUCTION}

In this developmental research, the design and development process of a new flipped learning environment is discussed.

The problem statement. In order to eliminate some of the limitations of flipped learning, the process of integrating and developing a discussion environment into the flipped learning environment constitutes the problem of this developmental study.

Analysis of recent studies and publications. In online learning environments, interaction problems affect students' satisfaction levels [1]. Increasing interaction in such environments positively affects success and performance [2]. In a study conducted by [3] on flipped learning classrooms, it was determined that the success levels of the students had also high satisfaction levels; however, it was also determined that, at the end of the flipped learning process, the satisfaction levels of the failed students were statistically significantly lower. They reported that if a more interactive and supportive flipped learning environment is 
provided, students will be able to achieve a better learning process. [4] reported that the desired interactions can be achieved if discussion environments are utilized in flipped learning environments, which in turn will positively affect learner performance. Similarly, [5] stated that in flipped learning environments, the interaction of students in various dimensions will improve by including discussions into the process, thus creating a more efficient learning environment. [6] and [7] stated that students can ask questions they have in mind during their out-of-school times through online discussion mediums.

The research goal. This research discusses the process of designing and developing a flipped learning environment, which is one of the blended learning approaches, through integrating the discussion environment in order to eliminate some of its limitations.

\section{THE THEORETICAL BACKGROUNDS}

The information age now we are living in significantly affects the technology field and continuously maintains its development. Developments in technology field affect many areas of our lives, from science to the humanities, and bring about profound changes across the globe. The field of educational technology is also directly affected by this development process and new approaches and methods are emerging in line with the social needs. One of these approaches is the flipped learning method, which has been frequently mentioned in recent years.

Flipped learning, in the simplest terms, is one of the blended learning methods [8] based on changing the role of the student's school environment and home environment [9]. According to this approach, while students conduct their "learning" in an out-of-school environment, the time in the classroom is allocated for exercises and practices rather than "learning". Students are expected to follow the content offered by their instructors during their out-of-school time, so that their preliminary knowledge levels are expected to reach a similar level [10]. In flipped learning method, the "learning" process often takes place with the help of videos provided by their instructors [11], [12]. These are usually the course videos that are previously recorded by the instructor. In this way, students perform their pre-learning before in-class courses that will be performed face-to-face [3]. When students come to the classroom environment, they continue their learning process by interacting with their peers, other students and instructors. At the in-class stage, instructors provide feedback and guide their students by enabling them to think and discuss [12]. In flipped learning, the instructor is not in the role of providing the information directly to the student, but works as a guide, creating the environment that the student needs to learn [13].

A UNESCO statement issued in April 2020 indicated that higher education institutions may prefer to adopt flipped learning approaches, especially supported by videos [14]. Similarly, in Turkey, the "New Normalization Process in the Global Pandemic Guide" published by the Council of Higher Education in July 2020 recommends that online supported methods such as flipped classroom be used by higher education institutions, thus saving time in the classroom and providing more effective and efficient teaching-learning processes [15]. In line with these suggestions, it can be said that the flipped learning method can be used by more educational institutions in the future.

Examining the relevant literature, it was observed that there are many advantages of this method, but despite these advantages, there are also some limitations. Flipped learning enables students to actively participate in learning processes by organizing their own learning. Students can perform their "learning" activity whenever and wherever they want [16]. It saves time and the time within the classroom can be used more effectively and efficiently [8]. Students can progress at their own learning pace [17], and additionally it improves their ability to solve problems and think critically [18]. In addition to these advantageous aspects, it 
has also been reported in many studies that the flipped learning method is particularly disadvantageous due to the fact that the students are alone in front of a computer screen with a course video. [19] reported that particularly the students, who can learn better by actively participating in the learning process, cannot learn only by sitting in front of a video; similarly, the instructor cannot be sure how much the student can learn from the video prepared by him/her. [20] and [21] stated that students need certain facilities such as the internet and computers to access the flipped learning system and that students need an adaptation process for the system. They reported that sitting alone in front of a video material, having no chance to ask questions, or having no immediate feedback are among the disadvantages, as well.

In the environments where flipped learning is performed, students may feel lonely and isolated in front of a computer ([17],[22],[23],[24],[25]). Similarly, in flipped learning environments, students may have difficulty in interacting with their friends or instructors ([17],[26],[21],[24],[27]). Students may not get help if they have a problem in the learning process during their out-of-class time [28]. Students may need a mentor who can guide them during the "learning" outside the classroom [29]. It was supposed that being left alone in front of a course video, feeling isolated and alone, having no access to any help, and being unable to interact would negatively influence students' learning. It can be stated that a more effective and efficient flipped learning environment can be created by eliminating these limitations and disadvantages.

In the present research, integrating the discussion into the traditional flipped learning environment was discussed in order to eliminate certain disadvantages or limitations reported in the literature. It is envisaged that a more effective and efficient flipped learning environment can be achieved by eliminating the interaction and communication problems that students experience during out-of-school times.

In traditional flipped learning environments, the learning process takes place outside the classroom through video contents provided by instructors ([11],[5]). In the newly-designed flipped learning environment, it is aimed to create a more efficient flipped learning environment by using an integrated discussion environment together with the course videos (Figure 1).

\begin{tabular}{|c|c|c|c|c|c|}
\hline \multicolumn{2}{|c|}{$\begin{array}{c}\text { Traditional } \\
\text { Flipped Learning Environment }\end{array}$} & \multicolumn{4}{|c|}{$\begin{array}{c}\text { Discussion-Oriented } \\
\text { Flipped Learning Environment }\end{array}$} \\
\hline - Implementation & & - Implementation & & & \\
\hline $\begin{array}{l}\text { - Exercise } \\
\text { - Practice }\end{array}$ & $\begin{array}{l}\text { Course } \\
\text { Videos }\end{array}$ & $\begin{array}{l}\text { - Exercise } \\
\text { - Practice }\end{array}$ & $\begin{array}{l}\text { Course } \\
\text { Videos }\end{array}$ & + & $\begin{array}{c}\text { Discussion } \\
\text { Environment }\end{array}$ \\
\hline - Short exams & & - Short exams & & & \\
\hline In-classroom & Non-classroom & In-classroom & & $n-c l$ & ssroom \\
\hline
\end{tabular}

Figure 1. Comparison of the Traditional and Discussion-Oriented Flipped Learning Environments

In Figure 1 representing the traditional structure, students devote their time in the classroom to implementation, exercise and practice, while only a video of the course is presented to them outside the classroom. In the new design, a communication module is planned to be installed, where students can continue their discussions and interact with their friends or instructors. Discussion-Oriented Flipped Learning Environment has been called DOFE for short.

\section{RESEARCH METHODS}

The method of research was determined as the developmental research. The developmental research model is used in studies that address the processes of designing, 
developing and evaluating a learning environment [30]. In the design and development process, the developmental research steps indicated by [31] were followed (Figure 2).

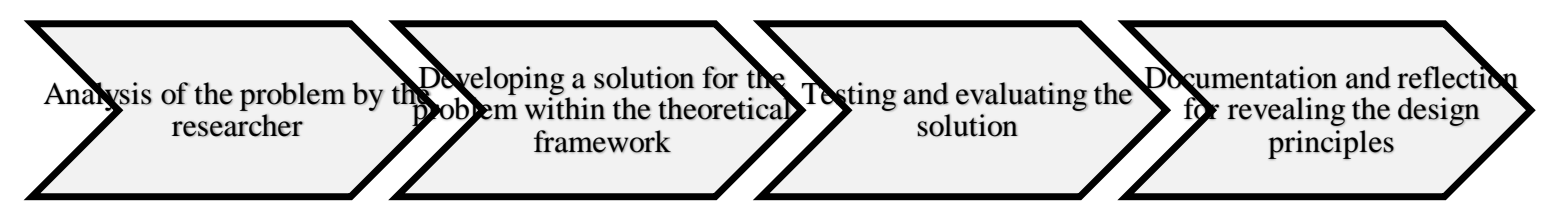

Figure 2. Developmental Research Steps [31]

According to [31], the first step for the researcher is to identify the problem. He reported further steps as developing a solution proposal for the problem identified within the theoretical framework and testing \& evaluating the new prototype structure. He stated that the final step is the documentation of the mentioned design steps through reporting. In this context, the researcher of this study examined the existing literature on flipped learning environments in particular, and revealed the problematic status of the flipped learning environments in terms of limitations and disadvantages. Additionally, upon the review of the relevant literature, possible solutions were designed and the process was started for integrating the discussion environment into the flipped learning environment.

\section{Participants}

For the environment expert assessment in the developmental research, opinions of nine field experts, one of whom was a Turkish language specialist, working in higher education institutions were taken. The participants of this research were 42 undergraduate students studying at Uşak University, who conducted an assessment for the newly-designed and developed DOFE.

\section{Data Collection Tools}

Among the data collection tools are the "Expert, Environment Assessment Form", which was prepared for taking the experts' opinions for the newly-designed and developed DOFE and the "Pilot Application Evaluation Form and Opinion Questionnaire" for taking the students' opinions. The expert opinion and evaluation form was comprised of three parts. General features of the DOFE were discussed in the first part, and the features of flipped learning environment were discussed in the second part. The last part included the items related to the visual design features of the DOFE. After the pilot application, the "Pilot Application Evaluation Form and Opinion Questionnaire" was filled by the students. The student evaluation form included the students' opinions and suggestions concerning the usefulness of the system and possible errors. The quantitative and qualitative data obtained were analyzed and reported in descriptive terms.

\section{Design and Development Process of Discussion-Oriented Flipped Learning Environment}

The DOFE began to be designed for the Computer Programming course offered at the undergraduate level. Prior to the development phase, it was decided by the researcher primarily on which infrastructure to develop the flipped learning environment. For this purpose, the existing learning management systems and content management systems were 
examined, and PHP-MySQL based Wordpress system was preferred, since it is a free, open source and creating plugins and interventional coding is simple. As of 2020, Wordpress is a content management system that forms the infrastructures of approximately $35 \%$ of all websites worldwide, which can be customized as desired, whether it is an e-learning platform or a shopping platform [32].

First, the Wordpress software was installed on a server with a Linux operating system. The server was made accessible with www.eogren.me domain name. In order to turn the content management system into a flipped learning environment, the theme was installed and visual and text changes were made on the template. In the prototype environment, six-week long video content sections were created in accordance with the computer programming course. The discussion environment was provided by the adaptation of the message board section which already exists in the Wordpress media. The message board was integrated into the content media by being transformed as a discussion environment (Figure 3 ).

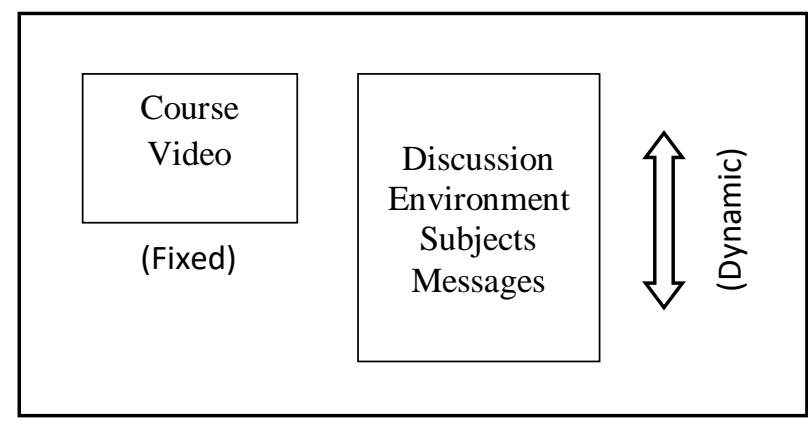

Figure 3. Student Screen and the Focus of Discussion

The discussion-oriented structure was provided through the integration of the discussion section and the video content environment. In the traditional web-based learning management systems, discussion forums are usually located under a different section, physically separated from the learning content. Students move away from the content environment when they switch to the discussion environment; similarly, they move away from the discussion environment when they switch to the content environment. In the study conducted by [33], it was determined that having discussion and content environments under different interfaces (physically different screens) created negativity in students' learning perceptions. In this study, it is possible for students to participate in discussions within the same screen, to be able to send messages and open a discussion topic in a way that is integrated with the learning content without moving away and without going to a different screen. This new design is called discussion-oriented flipped learning environment (Picture 1).
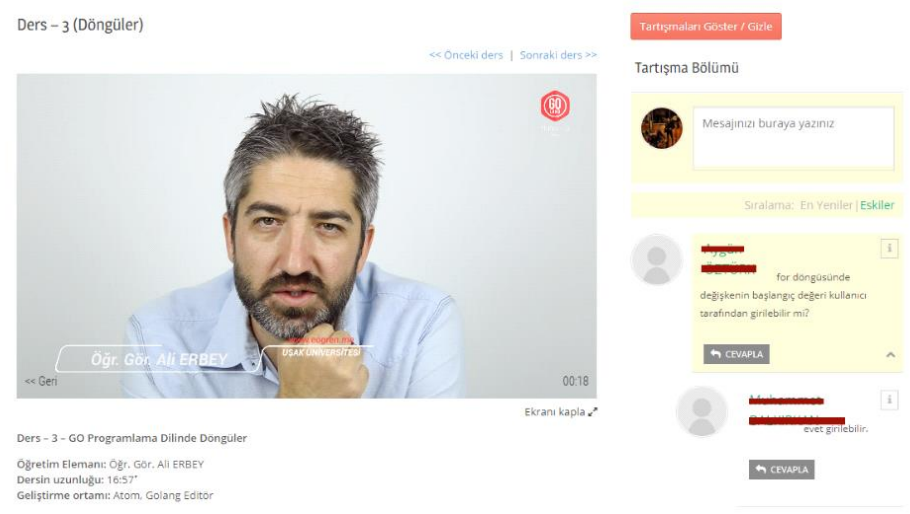

Picture 1. Discussion-Oriented Flipped Learning Environment Course Screen 
In a flipped learning environment, the course video is pinned to the left side on the screen. For this reason, the video player is enclosed in a partition (div) and this partition was fixed on the screen with the jQuery () functions. This allows the course video screen to stay in the same place continuously, even if the page is scrolled up and down. The discussion section is placed on the right side of the same screen. But the discussion section is not fixed to the screen unlike the video player. This section allows scrolling up and down for quick navigation among discussion messages. In this way, the student is enabled to follow the discussions while watching the course video without moving away from the course material, since he/she stays on the same screen. This design was named "focus of discussion".

The six-week computer programming course videos were recorded and assembled in a professional studio environment and then uploaded to the DOFE system. Discussionenvironments such as metadata, subject, duration, content, etc. about each course video were integrated with the course videos. With the help of the coding, the video player display was kept fixed even when navigating through discussions. In accordance with the testing and evaluation process, the third step of [31] developmental research began, namely, the opinions of experts were taken for the newly-designed prototype environment.

\section{Environment Expert Assessment}

The design "Expert Environment Assessment Form" was prepared and applied to take expert opinions about the prototype environment (Table-1). The form was submitted to eight field experts and one Turkish language expert. Experts examined the environment in three dimensions. They examined the general characteristics of the environment, flipped learning features and design characteristics. All experts were given a user name and password to access the system, allowing them to experience the environment freely. The experts used the prototype environment in detail and then filled out the evaluation form based on their experience. The experts examined the DOFE general features (choices: yes, available; not available; should be fixed).

Table 1

Environment assessment data for the experts (general features)

\begin{tabular}{|l|c|c|}
\hline Questions & f & \% \\
\hline 1) Flipped learning environment is always accessible through the www.eogren.me address. & 9 & 100 \\
\hline 2) Students use their username and password to log in to the system. & 9 & 100 \\
\hline 3) A student who logs in to the system joins his/her group directly. & 9 & 100 \\
\hline $\begin{array}{l}\text { 4) Students who log in to the system can access profile information, announcements and } \\
\text { communication sections. }\end{array}$ & 9 & 100 \\
\hline 5) There is a technical assistance section related to the system. & 9 & 100 \\
\hline 6) In the course area, there are explanations and information texts about the course. & 9 & 100 \\
\hline 7) In the course area, students can see profiles of other student friends. & 9 & 100 \\
\hline 8) Students can switch directly from the main page to the course areas. & 9 & 100 \\
\hline 9) Students can switch from the course area to the weekly-video course area. & 9 & 100 \\
\hline 10) In the course area, there are links to access 6-week video course content. & 9 & 100 \\
\hline
\end{tabular}

Based on the expert assessment about the general features of the DOFE, it was found that the predetermined characteristics exist in the newly-designed environment (Table 2). Subsequently, the experts examined the features of the DOFE flipped learning (choices: yes, available; not available; should be fixed). 
Table 2

\section{Environment assessment data for the experts (flipped features)}

\begin{tabular}{|l|c|c|}
\hline Questions & f & $\mathbf{\%}$ \\
\hline $\begin{array}{l}\text { 1) There are videos, discussion environment and information texts in the video lecture } \\
\text { environment. }\end{array}$ & 9 & 100 \\
\hline 2) Video and discussions are presented in an integrated way on the same screen. & 9 & 100 \\
\hline 3) As soon as the warning text on the video is clicked, the lesson video starts. & 9 & 100 \\
\hline $\begin{array}{l}\text { 4) During video playback, the student can stop or rewind 10 sec by clicking on the video from the } \\
\text { desktop computer. }\end{array}$ & 9 & 100 \\
\hline 5) Students can participate in (simultaneous) discussions while watching the video. & 9 & 100 \\
\hline $\begin{array}{l}\text { 6) Discussions are conducted in the form of a chain of opening the topic of discussion and } \\
\text { responding to previous topics that have been opened. }\end{array}$ & 9 & 100 \\
\hline $\begin{array}{l}\text { 7) Messages sent to the discussion environment and opened topics are automatically loaded } \\
\text { without the need to refresh the page. }\end{array}$ & 9 & 100 \\
\hline 8) Students can edit the discussion message and topic for 15 minutes after he/she sent the message. & 9 & 100 \\
\hline
\end{tabular}

The experts examined DOFE concerning the features of flipped learning and design. Based on the experts' feedback, it was found that the predetermined flipped learning features exist in the newly-designed environment. Lastly, the experts examined the visual design features of DOFE (choices: good and positive; bad, negative; should be fixed). Points concerning the visual design are given in Table-3.

Table 3

Environment pre-assessment data for the experts (visual design features)

\begin{tabular}{|l|c|c|}
\hline Questions & f & \% \\
\hline 1) What do you think about access speed to the www.eogren.me website? & 9 & 100 \\
\hline 2) What do you think about the visual interface design of the website? & 9 & 100 \\
\hline 3) What do you think about the fonts and font sizes used in the website? & 8 & 88.8 \\
\hline 4) What do you think about the harmony between the colors and visuals? & 9 & 100 \\
\hline 5) What do you think about the sound level and sound quality of the videos? & 9 & 100 \\
\hline 6) What do you think about the image quality of the videos? & 9 & 100 \\
\hline 7) What do you think about the loading speed of the videos? & 8 & 88.8 \\
\hline 8) What do you think about the visual design of the discussion section? & 9 & 100 \\
\hline 9) What do you think about the speed of switching among pages and loading pages? & 9 & 100 \\
\hline 10) What do you think about the placement and naming of the menu in the website? & 9 & 100 \\
\hline
\end{tabular}

An expert stated that the font sizes should be slightly larger. Another expert stated that the loading speed of the videos is a bit slow. The environment was finalized in line with the feedback from the experts.

\section{Pilot Application of the Environment and Student Assessment}

In order to test the newly-developed environment by the real users and to obtain user opinions, a pilot application was conducted with students and an assessment survey was implemented. A username and a password were provided for each of the 42 participant students (38\% female, $62 \%$ male) from the Faculty of Communication of Uşak University in order to access to the system, and the pilot application was conducted. Students were initially given a brief information about the system. They were then allowed to experience the environment freely. Subsequently, they were asked to complete the environment assessment form. In addition, students' written opinions and suggestions were taken about the environment (Table-4). 
Table 4

Environment assessment analysis for the students

\begin{tabular}{|l|c|c|c|c|}
\hline \multirow{2}{*}{ Questions } & \multicolumn{2}{|c|}{ Yes } & \multicolumn{2}{c|}{ No } \\
\cline { 2 - 5 } & $f$ & $\mathbf{\%}$ & $f$ & \% \\
\hline Did you have any problems using the www.eogren.me website? & 01 & 02.38 & 41 & 97.62 \\
\hline Did you feel getting lost while using the website? & 03 & 7.14 & 39 & 92.86 \\
\hline Did you have any navigating problems? & 06 & 14.29 & 36 & 85.71 \\
\hline $\begin{array}{l}\text { Are you satisfied with the speed of opening pages, speed of switching } \\
\text { from one page to another? }\end{array}$ & 36 & 85.71 & 06 & 14.29 \\
\hline Did you encounter a technical error on the website? & 03 & 7.14 & 39 & 92.86 \\
\hline $\begin{array}{l}\text { Did you watch the videos comfortably? Were the image and sound quality } \\
\text { satisfactory? }\end{array}$ & 36 & 85.71 & 06 & 14.29 \\
\hline In general terms, were you satisfied with the www.eogren.me website? & 38 & 90.48 & 04 & 09.52 \\
\hline
\end{tabular}

According to survey data obtained from 42 students who experienced the environment, initially, the problems that were experienced by a small number of students $(2.38 \%)$ and possible errors claimed by a small portion of students $(7.14 \%)$ were examined. It was determined that the problems faced by these students were caused by the computer they used, and therefore, no revision was made on the newly-designed system. However, the opinions, suggestions and complaints submitted by the students in writing were also addressed. Upon the evaluation of the student contributions, the environment was put into the final form. Ultimately, a system was created that met the general expectations of $90.48 \%$ of students.

The students' opinions, taken in the written form to further develop the system, were categorically classified, and reported in descriptive terms (Table-5).

Table 5

DOFE student opinions

\begin{tabular}{|l|c|c|}
\hline Opinions & f & \% \\
\hline Concerning the Environment & 5 & 11.90 \\
\hline Fast forward and rewind features should be added to the video player & 3 & 7.14 \\
\hline Audio on-off feature should be introduced & 5 & 11.90 \\
\hline $\begin{array}{l}\text { Visual quality should be increased and supported with colored } \\
\text { backgrounds and photos }\end{array}$ & 7 \\
\hline Concerning the Course & 4 & 16.66 \\
\hline A more fluent language should be used in lesson videos & 18 & 9.52 \\
\hline A funny narration can be used in boring subjects & $\mathbf{4 2}$ & $\mathbf{4 2 . 8 8}$ \\
\hline Other & $\mathbf{\% 1 0 0}$ \\
\hline Total & & \multicolumn{2}{|c|}{} \\
\hline
\end{tabular}

As a result of the descriptive analysis, it was observed that the students' opinions were mainly collected in two categories: related to the environment and related to the course. As per the visual design and media usefulness, the fast forward and rewind features were added to the video player in accordance with the students' demands. Furthermore, the audio on-off buttons were also added to the system. The instructor was encouraged to use a more fluent language in the course videos with a more active narration. According to the opinions obtained from the students, the environment was put into its final form with a revision.

\section{CONCLUSIONS AND PROSPECTS FOR FURTHER RESEARCH}

Flipped learning is one of the blended learning methods with a growing popularity in recent years. Particularly as of 2020, institutions such as Council of Higher Education and UNESCO are encouraging the spread of the use of flipped classroom practices. Therefore, it is expected that the flipped learning method will become even more popular in the following 
years. An in-depth study of the field related to this method points that there are a number of limitations and disadvantages related to the method. Flipped learning is a method, where the classroom learning and non-classroom applications of students are displaced by each other, and where learning is provided by videos [8]. However, it was supposed that being left alone in front of a course video, being unable to ask any questions, having no answers to the questions in mind, needing a guide, and having problems in interaction and communication would negatively influence students' learning process. In order to eliminate these limitations, it was decided to use discussion environments, one of the interaction and communication modules used in e-learning. It was aimed to introduce a new design by integrating the discussion environment into the flipped learning environment.

In this study, which was planned as a developmental research, the design processes determined by [31] were followed. Design-based research studies include steps aimed at running the theoretical foundation and educational technology applications together and in harmony [34]. According to these steps, initially, the problem with flipped learning environments was analyzed, a design idea was introduced to solve this problem, the designed environment was developed and submitted to the evaluation of experts, and the newlydeveloped environment was tested by conducting a pilot application and ultimately it was put into its final form.

In discussion-oriented flipped learning environments, students gained the chance to enter directly into discussions without moving away from their learning content. Students could not only read and write a discussion message, but also follow the course video on the same screen. This structure was called the 'focus of discussion'.

The newly-designed and developed DOFE was first introduced to the use of experts. The experts were allowed to experience the environment freely under similar conditions by connecting to the system on their own computers with the username and passwords allocated to them. They submitted their opinions by filling out the expert evaluation form prepared by the developer in three different sub-dimensions (General Features, Features About Flipped Learning, and Visual Design Characteristics). In accordance with the incoming opinions, certain improvements were made on the environment, and then the pilot application was tested with students. Concerning the course videos, students stated that the instructor should use a more fluent language and should make the course more enjoyable. Additionally, they reported that fast forward, rewind, and audio on-off options should be added on the video player screen, and the visual appearance should be more colorful. Based on these recommendations, audio on-off, fast forward, and rewind features were integrated into the environment.

After the application, the students made evaluations through the "Pilot Application Evaluation Form and Opinion Questionnaire" and conveyed their opinions. According to the students' opinions, DOFE was put into its final form by conducting ultimate revisions in the environment. $90.48 \%$ of students stated that they were satisfied with the system overall. [7] and [4] noted that the use of a discussion environment in flipped learning environments positively affects students' satisfaction levels. As a result of this research, it can be stated that a similar result was achieved.

Considering this new structure in terms of design principles and based on the fact that discussion environment can be integrated into the flipped learning environments, it can be expressed that discussion environments can be integrated directly into the learning material. This process can be performed within the learning management system whose infrastructure is used. In this way, when students interact with the course video materials provided by their instructors during out-of-school times, they can interact with their peers or instructors directly through the discussion environment if they need.

In order to fully demonstrate the effectiveness and efficiency of this new design, it is recommended to examine it with different dimensions and different variables. It is suggested 
that designers and practitioners can address different dimensions of discussion-oriented flipped learning environments.

\section{REFERENCES (TRANSLATED AND TRANSLITERATED)}

[1] H. Ilgaz, and P. Aşkar, "The Development of a Community Feeling Scale Toward Online Distance Education Environments," Turkish Journal of Computer and Mathematics Education, 1(1), pp. 27-34, 2009. (in Turkish)

[2] Üstündağ, M. T. "Çevrimiçi Öğrenme Ortamlarında Uyarlanmış Sosyal Etkileşim Araçlarının Öğrencilerin Akademik Başarılarına ve Sosyal Bulunuşluk Algılarına Etkisi,” Ankara: YÖK - Unpublished doctoral thesis.2012. (in Turkish)

[3] B. J. Beatty, Z. Merchant and M. Albert, "Analysis of Student Use of Video in a Flipped Classroom," Techtrends, pp. 376-385, 2017. (in English)

[4] Z. Zainuddin, "Implementing Moore's Model of Interaction in a Flipped-Class Instruction," The Online Journal of Distance Education and e-Learning, 6(3), pp. 10-20, 2018. (in English)

[5] R. Thakare, "8 Types of Flipped Learning Classrooms and Tools to Build Them. Industry," 2018. [Online]. Available: https://elearningindustry.com/flipped-learning-classrooms-tools-build-types (in English)

[6] J. M. Fautch, "The Flipped Classroom for Teaching Organic Chemistry in Small Classes: Is It Effective?" Chem. Educ. Res. Pract. (16), pp. 179-186, 2015. (in English)

[7] B. L. Hardin and D. A. Koppenhaver, "Flipped Professional Development: An Innovation in Response to Teacher Insights," Journal of Adolescent \& Adult Literacy, 60(1), pp. 45-54, 2016. (in English)

[8] J. Bergmann and A. Sams, "Flip Your Classroom: Reach Every Student in Every Class Every Day," International Society for Technology in Education, 2012. (in English)

[9] J. F. Strayer, "How Learning in An Inverted Classroom Influences Cooperation, Innovation and Task Orientation," Learning Environments Research, 2(15), pp. 171-193, 2012. (in English)

[10] J. Bergmann and A. Sams, "Flipped Learning: Gateway to Student Engagement. International Society for Technology in Education," 2014. (in English)

[11] Y. Chen, Y. Wang, Y. Kinshuk and N.-S. Chen, "Is FLIP Enough? Or Should We Use the Flipped Model Instead?" Computers \& Education, (79), pp. 16-27, 2014. (in English)

[12] G.-J. Hwang, C.-L. Lai and S.-Y. Wang, "Seamless Flipped Learning: A Mobile Technology-Enhanced Flipped Classroom with Effective Learning Strategies," Journal of Computers in Education, (2), pp. 449-473, 2015. (in English)

[13] A. Basal, "The Implementation of a Flipped Classroom in Foreign Language Teaching," Turkish Online Journal of Distance Education-TOJDE, 16(4), pp. 28-37, 2015. (in English)

[14] R. L. Huang, "Guidance on Flexible Learning During Campus Closures: Ensuring Course Quality of Higher Education in Covid-19 Outbreak. Beijing: Smart Learning Institute of Beijing Normal University." 2020. [Online]. Available: https://iite.unesco.org/wp-content/uploads/2020/05/Guidance-on-Flexible-Learningduring-Campus-Closures-in-COVID-19-outbreak-SLIBNU-V1.2_0508.pdf (in English)

[15] Turkish Council of Higher Education YÖK, "Küresel Salgında Yeni Normalleşme Süreci," Ankara: Yükseköğretim Kurulu, 2020. (in Turkish)

[16] R. S. Davies, D. L. Dean and N. Ball, "Flipping the Classroom and Instructional Technology Integration in A College-Level Information Systems Spreadsheet Course," Education Tech Research Dev. (61), pp. 563-580, 2013. (in English)

[17] N. B. Milman, "The Flipped Classroom Strategy: What Is It and How Can It Best Be Used?" Distance Learning, 9(3), pp. 85-87, 2012. (in English)

[18] M. K. Lee and B. K. Park, "Effects of Flipped Learning Using Online Materials in A Surgical Nursing Practicum: A Pilot Stratified Group-Randomized Trial," Healthcare Informatics Research, 1(24), pp. 69-78, 2018. (in English)

[19] E. Crockett, "The Cons of a Flipped Classroom. The Roar - The Official Student Newspaper of Brentsville District High School," 2019. [Online]. Available: https://bdhs-theroar.org/3772/editorials/the-cons-of-aflipped-classroom/ (in English)

[20] Z. Turan and Z. Göktaş, "A New Approach in Higher Education: The Students' Views on Flipped Classroom Method," Yüksekögretim ve Bilim Dergisi, pp. 156-164, 2015. (in Turkish)

[21] K. K., Bhagat, C. N., Chang and C. Y. Chang, "The Impact of The Flipped Classroom on Mathematics Concept Learning in High School," Journal of Educational Technology \& Society, pp. 134-142, 2016. (in English)

[22] R. Talbert, "Inverted classroom. Colleagues," 2012. [Online]. 9(1), 1-3. Available: https://scholarworks.gvsu.edu/cgi/viewcontent.cgi?article=1183\&context=colleagues (in English)

[23] S. C., Du, Z. T., Fu and Y. Wang, "The Flipped Classroom-Advantages and Challenges," International Conference on Economic Management and Trade Cooperation, pp. 17-20. Atlantis Press. 2014. (in English) 
[24] J. Nouri, "The Flipped Classroom: For Active, Effective and Increased Learning - Especially for Low Achievers, ” International Journal of Educational Technology in Higher Education, 13(33), pp. 1-10. 2016. (in English)

[25] C. Jenkins, "The Advantages and Disadvantages of the Flipped Classroom. Echo360," 2017. [Online]. Available: http://blog.echo360.com/blog/bid/59158/The-Advantages-and-Disadvantages-of-the-FlippedClassroom (in English)

[26] J. O'Flaherty and C. Phillips, "The Use of Flipped Classrooms in Higher Education: A Scoping Review," Internet and Higher Education, (25), pp. 85-95, 2015. (in English)

[27] A. Y. Gündüz and B. Akkoyunlu, "Dönüştürülmüş Sınıftan Dönüştürülmüş Öğrenmeye," Eğitim Teknolojileri Okumalart TOJET, pp. 237-251, 2016. (in Turkish)

[28] L. Chen, T.-L. Chen and N.-S. Chen, "Students' Perspectives of Using Cooperative Learning in a Flipped Statistics Classroom," Australasian Journal of Educational Technology, 31(6), pp. 621-640, 2015. (in English)

[29] T. Wanner and E. Palmer, "Personalizing Learning: Exploring Student and Teacher Perceptions About Flexible Learning and Assessment in a Flipped University Course," Computers \& Education, (88), pp. 354-369, 2015. (in English)

[30] R. C. Richey, "Developmental Research: The Definition and Scope," National Convention of the Association for Educational Communications and Technology (s. 714-720). Nashville: Educational Research and Improvement - ERIC, 1994. (in English)

[31] T. C. Reeves, "Enhancing the Worth of Instructional Technology Research through "Design Experiments" and Other Development Research Strategies," International Perspectives on Instructional Technology Research for the 21st Century, pp. 1-15, New Orleans, LA, USA. 2000. (in English)

[32] Wordpress, "Democratize Publishing. Wordpress" 2020 [Online]. Available: https://wordpress.org/about/ (in English)

[33] E. O. Yılmaz and H. Yurdugül, "E-Öğrenmede Kavram Tabanlı Tartışma Ortamının Tasarımı ve Etkililiği," 2. Eurasian Educational Research Congress EJER2014, 2014. (in Turkish)

[34] A. Kuzu, S. ÇankayaandZ. A. Misırlı, "Design-Based Research and Its Implementation in the Design and Development of Learning Environments," Anadolu Journal of Educational Sciences International, 1(1), pp. 19-36. 2011. (in Turkish)

Text of the article was accepted by Editorial Team 07.02.2021

\title{
ПРОЄКТУВАННЯ ТА РОЗРОБКА ДИСКУСІЙНО ОРІЄНТОВАНОГО СЕРЕДОВИЩА ПЕРЕВЕРНУТОГО НАВЧАННЯ СТУДЕНТІВ
}

\author{
Ерді Окан Їлмаз \\ $\mathrm{PhD}$, доктор, викладач \\ Університет Ушак, Центр додатків для дистанційної освіти і досліджень, м. Ушак, Туреччина \\ ORCID ID 0000-0002-7423-725X \\ erdi.yilmaz@usak.edu.tr \\ Нуреттін Шімшек \\ $\mathrm{PhD}$, професор, доктор \\ Університет Анкари, Департамент комп'ютерних освітніх технологій, м. Анкара, Туреччина \\ ORCID ID 0000-0002-9319-1875 \\ nsimsek@ankara.edu.tr
}

\begin{abstract}
Анотація. У дослідженні обговорюється процес проєктування і розробки середовища перевернутого навчальння, як однієї з моделей змішаного навчання з метою розширення його можливостей шляхом інтеграції дискусійного середовища. У цьому контексті для поліпшення взаємодії студентів дискусійне середовище було інтегроване в традиційне середовище перевернутого навчання. Середовище було розроблено в такий спосіб, щоб студенти могли одночасно мати доступ на своїх комп'ютерах до навчального контенту, а також можливість проводити дискусії. Метод дослідження визначено як експериментальне дослідження. Відповідно до етапів дослідження були виконані етапи проєктування та розробки середовища. У ході розробки середовища використовувались бази даних PHP, JavaScript i Mysql. Була використана система управління контентом WordPress, відеоролики курсів записані в професійній студії, етапи редагування і виробництва виконувались дослідником. Новий спроєктований і розроблений прототип середовища був протестований дев'ятьма експертами і 42 студентами бакалаврату, які навчаються в Ушакському університеті в Туреччині. Для оцінки розробленого пілотного середовища використовувалась «Форма експертної оцінки середовища»
\end{abstract}


для отримання експертного висновку та «Форма оцінки пілотного додатку і опитувальник» для отримання думки студентів. Висновок експерта і форма оцінки складались із трьох частин: у першій обговорювались загальні характеристики дискусійно орієнтованого середовища перевернутого навчання, у другій - особливості середовища перевернутого навчання, остання частина містила елементи, пов'язані з особливостями візуального дизайну нового середовища. Було визначено ставлення студентів та експертів, проведено оцінювання, після чого навчальне середовище отримало відповідну форму. Можна констатувати, що зміна середовища перевернутого навчання в дискусійно-орієнтовану структуру має позитивний ефект задоволення студентів середовищем навчання.

Ключові слова: дискусійно орієнтоване перевернуте навчання; експериментальне дослідження; перевернуте навчання.

\title{
ПРОЕКТИРОВАНИЕ И РАЗРАБОТКА ДИСКУССИОННО- ОРИЕНТИРОВАННОЙ СРЕДЫ ПЕРЕВЕРНУТОГО ОБУЧЕНИЯ СТУДЕНТОВ
}

\author{
Эрди Окан Илмаз \\ $\mathrm{PhD}$, доктор, преподаватель \\ Университет Ушак, Центр приложений дистанционного образования и исследований, г. Ушак, Турция \\ ORCID ID 0000-0002-7423-725X \\ erdi.yilmaz@usak.edu.tr
}

\section{Нуреттин Шимшек}

$\mathrm{PhD}$, профессор, доктор

Университет Анкары, Департамент компьютерных образовательных технологий, г. Анкара, Турция ORCID ID 0000-0002-9319-1875

nsimsek@ankara.edu.tr

\begin{abstract}
Аннотация. В исследовании обсуждается процесс проектирования и разработки среды перевернутого обучения, которая является одним из подходов смешанного обучения, с целью расширения его возможностей путем интеграции дискуссионной среды. В этом контексте, для улучшения взаимодействия студентов, дискуссионная среда была интегрирована в традиционную среду перевернутого обучения. Среда была разработана таким образом, чтобы студенты могли иметь одновременно на своих компьютерах доступ к учебному контенту, а также возможность обсуждения. Метод исследования определен как экспериментальное исследование. В соответствии с этапами исследования были выполнены этапы проектирования и разработки среды. В процессе разработки среды использовались базы данных PHP, JavaScript и Mysql. Была использована система управления контентом WordPress, видеоролики курсов были записаны в профессиональной студии, этапы редактирования и производства выполнялись исследователем. Новый спроектированный и разработанный прототип среды был протестирован девятью экспертами и 42 студентами бакалавриата, обучающимися в Ушакском университете в Турции. Для оценки разработанной пилотной среды использовалась «Форма экспертной оценки среды» для получения экспертного заключения и «Форма оценки пилотного приложения и опросник» для получения мнения студентов. Заключение эксперта и форма оценки состояли из трех частей: в первой обсуждались общие характеристики дискуссионно-ориентированной среды перевернутого обучения, во второй - особенности среды перевернутого обучения, последняя часть включала элементы, связанные с особенностями визуального дизайна новой среды. Были получены мнения студентов и экспертов, проведено оценивание, после чего среда обучения приобрела соответствующую форму. В результате можно констатировать, что изменение перевернутой среды обучения в дискуссионно-ориентированную структуру имеет положительный эффект на удовлетворенность студентов средой обучения.
\end{abstract}

Ключевые слова: дискуссионно-ориентированное перевернутое обучение; экспериментальное исследование; перевернутое обучение.

\section{(c) BY-NC-SA}

ThisworkislicensedunderCreativeCommonsAttribution-NonCommercial-ShareAlike 4.0 InternationalLicense 